fusidic acid/l inhibits the excretion of conjugated bilirubin, and at $3000-5000 \mathrm{mg} / \mathrm{l}$ there is competitive inhibition of conjugation. These concentrations are considerably greater than any likely to have been reached in our patients. In six out of 32 patients who became jaundiced during treatment with intravenous fusidic acid, however, the serum alkaline phosphatase activity increased; and the bilirubin was predominantly conjugated in the three patients in whom conjugated and unconjugated concentrations were measured. These findings may indicate that the jaundice was cholestatic in a few cases. For the rest we have no evidence for such a mechanism. A careful prospective investigation would be needed to elucidate the mechanism of the jaundice associated with fusidic acid treatment.

Since the jaundice is reversible and the clinical results obtained with fusidic acid in severe staphylococcal sepsis are excellent, the continuing use of this valuable agent would seem to be justified. We make the following suggestions. Firstly, the intravenous preparation should be made up in the volume recommended by the manufacturer $(500 \mathrm{ml})$ or in the maximum volume compatible with the patient's clinical condition and infused slowly over at least six to eight hours. Secondly, as soon as the patient's condition permits the oral form of the drug should be used. Thirdly, liver function should be monitored regularly in any patient receiving intravenous fusidic acid. Should the bilirubin concentration continue to rise when the patient is given oral fusidic acid the drug should be stopped. In patients already jaundiced a further increase in bilirubin concentration during treatment with fusidic acid is also an indication for stopping the drug, although the cause of the deterioration in liver function can seldom be determined.

We thank the many doctors at St Thomas's Hospital for permission to study their patients; and Dr B Slavin, Miss P Kind, the staff of the department of clinical chemistry, Dr R Pounder, and Mr A P Menday (Leo Laboratories) for help and advice.

Requests for reprints should be sent to Professor I Phillips.

\section{References}

1 Jensen K, Lassen HCA. Fulminating staphylococcal infections treated with Fucidin and penicillin or semi-synthetic penicillin. Ann Intern Med $1964 ; 60: 790-8$.

2 Jensen K, Lassen HCA. Combined treatment with antibacterial chemotherapeutic agents in staphylococcal infections. $Q \mathcal{F}$ Med 1969;38: 91-106.

3 Blockey NJ, McAllister TA. Antibiotics in acute osteomyelitis in children. f Bone foint Surg 1972;54B:299-309.

4 Wright GLT, Harper J. Fusidic acid and lincomycin therapy in staphylococcal infections in cystic fibrosis. Lancet 1970;i :9-14.

5 Barber M, Waterworth PM. Antibacterial activity in vitro of Fucidin. Lancet $1962 ; \mathrm{i}: 931-2$.

${ }^{6}$ Lowbury EJL, Cason JS, Jackson DMacG, Miller RWS. Fucidin for staphylococcal infection of burns. Lancet $1962 ; \mathrm{ii}: 478-80$.

7 Paton A. Drug jaundice. Br Med f 1976;ii:1126-7.

${ }^{8}$ Keeling PWN, Thompson RPH. Drug-induced liver disease. Br Med $\mathcal{F}$ $1979 ; \mathrm{i}: 990-3$.

${ }^{9}$ Ernst J. Fucidin behandlung ved kroniske stafylokokostitter og osteomyelitter. Ugeskr Laeger 1969;131:779-83.

10 Menday AP, March BT. Intravenous fusidic acid in the management of severe staphylococcal infections: a review of 46 cases. Curr Med Res Opin 1976;4:132-8.

11 Copperman IJ. The prolonged use of intravenous fusidic acid in severe staphylococcal infection. Br f Clin Pract 1972;26:83-4.

12 Craig JA. Jaundice in acute pustular psoriasis. Br Med $\mathcal{F} 1974 ;$ iii 43.

${ }^{13}$ Fahrlander H, Huber F, Gloor F. Intra-hepatic retention of bile in severe bacterial infections. Gastroenterology 1964;47:590-9.

14 Parsons RL, Beavis JP, Paddock GM, David JA, Trounce JR. Additives to intravenous fluids. $B r$ Med $\mathcal{F} 1976$;iv: 1256 .

15 Godtfredsen WO, Vangedal S. On the metabolism of fusidic acid in man. Acta Chem Scand 1966;20:1599-607.

(Accepted 11 March 1980)

\title{
Adverse reactions to D-penicillamine after gold toxicity
}

\author{
M J DODD, I D GRIFFITHS, M THOMPSON
}

\section{Summary and conclusions}

The incidence of adverse reactions to $D$-penicillamine in 155 patients with rheumatoid arthritis was analysed and compared with their history of adverse reactions to gold. Out of 125 patients who took only D-penicillamine, 45 developed side effects from the drug, whereas of 27 patients with a history of gold toxicity, 18 also reacted adversely to D-penicillamine. All patients who took $\mathrm{D}$-penicillamine within six months after an adverse reaction to gold developed side effects from D-penicillamine. Fourteen patients developed similar adverse reactions to $D$-penicillamine and gold, and the interval between treatments in this group was significantly shorter $(p<0.01)$ than in those who developed either differing adverse reactions to both drugs or no reaction to $\mathrm{D}$-penicillamine after treatment with gold.

An interval exceeding six months between treatment with gold and treatment with $D$-penicillamine in patients who have developed adverse reactions to gold apparently reduces the risk of adverse reactions to $D$-penicillamine.

\footnotetext{
Department of Rheumatology, Freeman Hospital, Newcastle upon Tyne NE1 4LP

M J DODD, MB, MRCP, senior registrar

I D GRIFFITHS, MB, MRCP, consultant rheumatologist

M THOMPSON, MD, FRCP, consultant rheumatologist
}

\section{Introduction}

Both gold salts and D-penicillamine are effective against rheumatoid arthritis, and the therapeutic responses to the two drugs are apparently similar. ${ }^{1}$ Although both drugs produce a high incidence of adverse reactions, ${ }^{23}$ it has not been clearly established whether patients reacting adversely to gold are more likely to develop adverse reactions to D-penicillamine.

Day and Golding ${ }^{4}$ noted that three out of four patients who developed bone marrow depression while taking D-penicillamine had already taken gold, and a later report ${ }^{5}$ implied that rashes and blood dyscrasias were more common in patients taking D-penicillamine who had already taken gold. A multicentre trial group, however, failed to show any association between the two drugs in terms of adverse reactions. ${ }^{\circ}$

We have analysed retrospectively the incidence of adverse reactions in patients treated with $\mathrm{D}$-penicillamine and related these findings to their history of adverse reactions to gold.

\section{Patients, methods, and results}

One hundred and fifty-five patients took D-penicillamine for rheumatoid arthritis, 30 of whom had already been treated with gold (sodium aurothiomalate), which was stopped because of either adverse reactions $(n=27)$ or lack of benefit $(n=3)$. Eighteen of the 27 patients $(67 \%)$ who stopped taking gold because of side effects also reacted adversely to $D$-penicillamine necessitating withdrawal of 
treatment, and in 14 of these similar side effects from each drug were observed (table I). Of the remaining 125 patients who had not been treated with gold, $45(36 \%)$ developed adverse reactions. From these observations apparently those patients who reacted adversely to gold were more likely to have adverse reactions to $\mathrm{D}$-penicillamine $\left(\chi^{2}=7 \cdot 39, \mathrm{df}=1, \mathrm{p}<0 \cdot 01\right)$.

We divided the 27 patients with a history of gold toxicity who were subsequently treated with $\mathrm{D}$-penicillamine into two groups-namely, those developing identical adverse reactions to both drugs $(n=14$; table I), and those not developing an adverse reaction to $D$-penicillamine $(n=9)$ or developing different side effects from both drugs $(n=4)$ (table II). Although the total amount of gold given to the two groups was similar, the mean interval between finishing treatment with gold and beginning treatment with $\mathrm{D}$-penicillamine was 3.9 months in the group developing identical adverse reactions and 12.6 months in the second group; the difference was significant at the $1 \%$ level. The pattern of adverse reactions to gold in the 27 patients who reacted adversely to gold and who subsequently received D-penicillamine was not significantly different from that in a control group of 64 patients who developed side effects from gold but did not subsequently receive $D$-penicillamine.

\section{Discussion}

Our findings suggest that patients who have adverse reactions to gold are significantly more likely to develop side effects from D-penicillamine. The patients were not preselected for susceptibility to certain types of drug allergy since the pattern of toxic reactions to gold was no different from that in patients treated with gold only. Our results differ from those of Webley and Coomes, ${ }^{5}$ who failed to find a significant increase in the incidence of adverse reactions to D-penicillamine in patients who had already taken gold. We, however, considered only patients who had shown gold toxicity, whereas their study included all patients who had taken gold, whether they had developed adverse reactions or not.

D-penicillamine chelates heavy metals, ${ }^{7}$ and gold may be stored in tissue for prolonged periods after the end of treatment. ${ }^{8}$ Hence some adverse reactions to D-penicillamine seen in patients after treatment with gold may result from mobilisation of gold in the tissues. This hypothesis is supported by our finding that the mean interval between finishing treatment with gold and beginning treatment with $\mathrm{D}$-penicillamine in patients who developed identical adverse reactions to both drugs was significantly shorter ( 3.9 months) than the interval in those who either did not react adversely to $D$-penicillamine (13.0 months) or had differing side effects (11.75 months). Also, patients with intervals of over six months between treatments showed an incidence of adverse reactions to D-penicillamine (25\%) similar to that in patients who took only D-penicillamine $(36 \%)$, whereas all patients who took D-penicillamine within six months of an adverse reaction to gold developed side effects from D-penicillamine, which were similar in 13 out of 15 patients.

An alternative explanation is that patients develop crossreactivity to the thiol derivatives common to both drugs. This could be tested by reversing the order of treatments. At present, however, we do not have enough patients treated with D-

TABLE I-Amounts given and durations of treatment with gold and D-penicillamine and adverse reactions in patients in whom these were identical to both drugs

\begin{tabular}{|c|c|c|c|c|c|c|c|}
\hline \multirow[b]{2}{*}{ Case No } & \multicolumn{3}{|c|}{ Treatment with gold* } & \multirow{2}{*}{$\begin{array}{c}\text { Interval } \\
\text { between } \\
\text { treatments } \\
\text { (months) }\end{array}$} & \multicolumn{3}{|c|}{ Treatment with D-penicillamine } \\
\hline & Total amount (mg) & $\begin{array}{l}\text { Duration } \\
\text { (months) }\end{array}$ & Adverse reaction & & Dosage (mg/24th) & $\begin{array}{l}\text { Duration } \\
\text { (months) }\end{array}$ & Adverse reaction \\
\hline $\begin{array}{r}1 \\
2 \\
3 \\
4 \\
5 \\
6 \\
7 \\
8 \\
9 \\
10\end{array}$ & $\begin{array}{r}680 \\
20 \\
1150 \\
890 \\
550 \\
80 \\
2615 \\
1000 \\
330 \\
330\end{array}$ & $\begin{array}{r}4 \\
1 \\
10 \\
6 \\
4 \\
1 \\
23 \\
11 \\
7 \\
5\end{array}$ & $\begin{array}{l}\text { Rash } \\
\text { Rash } \\
\text { Rash } \\
\text { Proteinuria } \\
\text { Proteinuria } \\
\text { Proteinuria } \\
\text { Neutropenia } \\
\text { Neutropenia } \\
\text { Mouth ulcers } \\
\text { Vomiting and } \\
\text { diarrhoea }\end{array}$ & $\begin{array}{r}5 \\
2 \\
4 \\
12 \\
3 \\
1 \\
4 \\
3 \\
2 \\
6\end{array}$ & $\begin{array}{l}125 \\
125 \\
275 \\
125 \\
125 \\
250 \\
450 \\
250 \\
125 \\
250\end{array}$ & $\begin{array}{l}3 \\
2 \\
8 \\
3 \\
3 \\
4 \\
2 \\
2 \\
2 \\
8\end{array}$ & $\begin{array}{l}\text { Rash } \\
\text { Rash } \\
\text { Rash } \\
\text { Proteinuria } \\
\text { Proteinuria } \\
\text { Proteinuria } \\
\text { Neutropenia } \\
\text { Neutropenia } \\
\text { Mouth ulcers } \\
\text { Vomiting and } \\
\text { diarrhoea }\end{array}$ \\
\hline $\begin{array}{l}11 \\
12 \\
13 \\
14\end{array}$ & $\begin{array}{r}2200 \\
830 \\
330 \\
1990\end{array}$ & $\begin{array}{r}22 \\
4 \\
2 \\
27\end{array}$ & $\begin{array}{l}\text { Haematuria } \\
\text { Rash } \\
\text { Rash } \\
\text { Rash }\end{array}$ & $\begin{array}{l}5 \\
1 \\
1 \\
5\end{array}$ & $\begin{array}{l}125 \\
125 \\
125 \\
250\end{array}$ & $\begin{array}{l}3 \\
3 \\
4 \\
7\end{array}$ & $\begin{array}{l}\text { Haematuria } \\
\text { Rash } \\
\text { Rash } \\
\text { Rash }\end{array}$ \\
\hline Mean & $928 \cdot 2$ & $9 \cdot 1$ & & 3.9 & $194 \cdot 6$ & 3.9 & \\
\hline
\end{tabular}

*Given as sodium aurothiomalate.

TABLE II-Amounts given and durations of treatment with gold and D-penicillamine and adverse, reactions in patients showing adverse reactions only to gold or differing adverse reactions to both drugs

\begin{tabular}{|c|c|c|c|c|c|c|c|}
\hline \multirow[b]{2}{*}{ Case No } & \multicolumn{3}{|c|}{ Treatment with gold* } & \multirow{2}{*}{$\begin{array}{c}\text { Interval } \\
\text { between } \\
\text { treatments } \\
\text { (months) }\end{array}$} & \multicolumn{3}{|c|}{ Treatment with D-penicillamine } \\
\hline & Total amount (mg) & $\begin{array}{l}\text { Duration } \\
\text { (months) }\end{array}$ & Adverse reaction & & Dosage (mg/24h) & $\begin{array}{l}\text { Duration } \\
\text { (months) }\end{array}$ & Adverse reaction \\
\hline $\begin{array}{l}15 \\
16 \\
17 \\
18\end{array}$ & $\begin{array}{l}720 \\
530 \\
530 \\
130\end{array}$ & $\begin{array}{r}11 \\
5 \\
4 \\
2\end{array}$ & $\begin{array}{l}\text { Thrombocytopenia } \\
\text { Rash } \\
\text { Rash } \\
\text { Rash }\end{array}$ & $\begin{array}{r}4 \\
16 \\
26 \\
1\end{array}$ & $\begin{array}{l}500 \\
175 \\
125 \\
500\end{array}$ & $\begin{array}{r}6 \\
3 \\
1 \\
36\end{array}$ & $\begin{array}{l}\text { Rash } \\
\text { Proteinuria } \\
\text { Proteinuria } \\
\text { Proteinuria }\end{array}$ \\
\hline $\begin{array}{c}\text { Mean } \\
(n=4)\end{array}$ & $477 \cdot 5$ & $5 \cdot 5$ & & $11 \cdot 75$ & $325 \cdot 0$ & $11 \cdot 5$ & \\
\hline $\begin{array}{l}19 \\
20\end{array}$ & $\begin{array}{l}1270 \\
2340\end{array}$ & $\begin{array}{l}36 \\
19\end{array}$ & $\begin{array}{l}\text { Rash } \\
\text { Rash and } \\
\text { proteinuria }\end{array}$ & $\begin{array}{l}24 \\
13\end{array}$ & $\begin{array}{l}250 \\
500\end{array}$ & $\begin{array}{r}5 \\
11\end{array}$ & 二 \\
\hline $\begin{array}{l}21 \\
22 \\
23 \\
24 \\
25 \\
26 \\
27\end{array}$ & $\begin{array}{r}105 \\
50 \\
160 \\
380 \\
1800 \\
860 \\
380\end{array}$ & $\begin{array}{r}1 \\
1 \\
2 \\
2 \\
24 \\
7 \\
2\end{array}$ & $\begin{array}{l}\text { Rash } \\
\text { Rash } \\
\text { Rash } \\
\text { Proteinuria } \\
\text { Rash } \\
\text { Rash } \\
\text { Rash }\end{array}$ & $\begin{array}{r}13 \\
9 \\
12 \\
10 \\
7 \\
8 \\
21\end{array}$ & $\begin{array}{l}250 \\
375 \\
250 \\
375 \\
500 \\
250 \\
500\end{array}$ & $\begin{array}{r}17 \\
17 \\
41 \\
38 \\
8 \\
1 \\
26\end{array}$ & $\begin{array}{l}\bar{z} \\
\bar{z} \\
=\end{array}$ \\
\hline $\begin{array}{c}\text { Mean } \\
(\mathrm{n}=9)\end{array}$ & $816 \cdot 1$ & $10 \cdot 4$ & & $13 \cdot 0$ & $361 \cdot 1$ & $18 \cdot 2$ & \\
\hline $\begin{array}{c}\text { Combined mean } \\
(n=13)\end{array}$ & $711 \cdot 9$ & $8 \cdot 9$ & & $12 \cdot 6$ & 350 & $16 \cdot 1$ & \\
\hline
\end{tabular}

- Given as sodium aurothiomalate. 
penicillamine and subsequently with gold to test this hypothesis.

We believe that the increased incidence of adverse reactions to D-penicillamine in patients with a history of gold toxicity is related to the short interval between the two treatments in many cases. Hence treatment with D-penicillamine in a patient who has reacted adversely to gold should probably be delayed for at least six months after gold, when the risk of further adverse reactions is apparently reduced.

\section{References}

${ }^{1}$ Huskisson EC, Gibson TJ, Balme HW, et al. Trial comparing Dpenicillamine and gold in rheumatoid arthritis. Ann Rheum Dis 1974 ; $33: 532-5$.
${ }^{2}$ Multicentre trial group. Controlled trial of D-penicillamine in severe rheumatoid arthritis. Lancet $1973 ; \mathrm{i}: 275-80$.

${ }^{3}$ Girdwood RH. Death after taking medicaments. Br Med f 1974; ; :501-4.

4 Day AT, Golding JR. Hazards of penicillamine therapy in the treatment of rheumatoid arthritis. Postgrad Med $\mathcal{F} 1974 ; 50$, suppl $2: 71-3$.

5 Webley M, Coomes EN. Is penicillamine therapy in rheumatoid arthritis influenced by previous treatment with gold? $B r$ Med 7 1978;ii:91.

${ }^{6}$ Multicentre trial group. Absence of toxic or therapeutic interaction between penicillamine and previously administered gold in a trial of penicillamine in rheumatoid disease. Postgrad Med $\mathcal{F} 1974 ; 50$, suppl 2: 77-8.

7 Walshe JM. Wilson's disease. New oral therapy. Lancet 1956;i :25-6.

8 Vernon-Roberts B, Dove JL, Jessop JD, Henderson WJ. Selective concentration and localisation of gold in macrophages of synovial and other tissues during and after chrysotherapy in rheumatoid patients. Ann Rheum Dis 1976;35:477-86.

(Accepted 18 March 1980)

\title{
Insulin-induced lipoatrophy: evidence for an immune pathogenesis
}

\author{
W G REEVES， B R ALLEN， R B TATTERSALL
}

\section{Summary and conclusions}

Skin biopsy samples from 14 diabetic patients with lipoatrophy at injection sites and from five insulintreated diabetic patients without such lipoatrophy (controls) were examined by immunofluorescence for the deposition of immunological components. Also sera from 13 of the patients with lipoatrophy and from all of the controls were assayed for insulin-binding capacity.

Biopsy samples from the edge of lipoatrophic areas (eight cases) invariably showed abnormal deposition of immunological components in dermal vessel walls, whereas no such deposition was seen in the control samples. Mean serum insulin-binding capacity was $33 \cdot 1$ $\mu \mathrm{g} / \mathrm{l}$ in the patients with lipoatrophy compared with only $4.6 \mu \mathrm{g} / 1$ in the controls.

These findings suggest that insulin-induced lipoatrophy results from the local formation of immune complexes, complement fixation, and release of inflammatory mediators from the cellular infiltrate.

\section{Introduction}

Lipoatrophy at injection sites is a common complication of treatment with insulin and has been reported in $10 \%, 124 \%$, and $55 \%^{3}$ of patients treated with conventional bovine insulins. Many theories have been proposed, but the exact pathogenesis remains obscure. Lipoatrophy is almost unknown in patients treated only with highly purified porcine insulins, ${ }^{14}$ which prompted us to examine the role of immunological factors in its pathogenesis.

\section{Patients and methods}

We studied one man and 13 women with moderate or severe lipoatrophy. Their mean age was 45 years (range 15-74) and the mean

University Hospital, Nottingham NG7 2UH

W G REEVES, BSC, FRCP, consultant immunologist and senior lecturer B R ALLEN, MB, MRCP, consultant dermatologist R B TATTERSALL, MD, MRCP, consultant physician duration of treatment with insulin 11 years (range four months to 30 years). Five insulin-treated patients (three women and two men) without evidence of lipoatrophy served as controls; they were younger than the study group (mean age 25 years) but had been treated with insulin for a similar time (mean 10 years) (see table I). Figure 1 shows the clinical appearance of the lipoatrophy in case 1 .

TABLE I-Sex, age, serum insulin binding capacity (IBC), and details of treatment with insulin in 14 patients with lipoatrophy and in five control patients

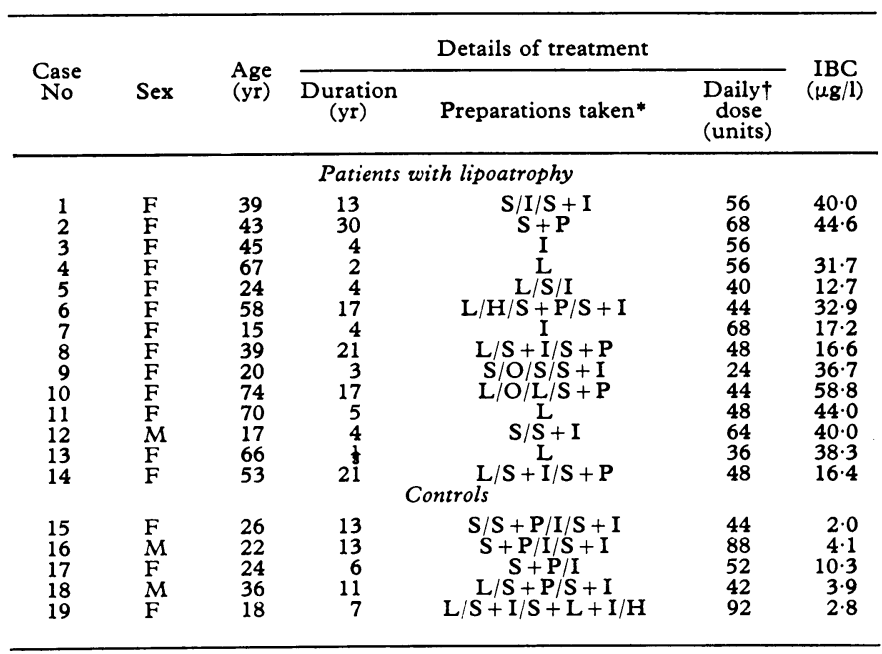

* $/=$ Change to different regimen. $+=$ Preparations taken together. $S=$ Soluble $\mathrm{I}=$ Isophane. $\mathrm{P}=$ Protamine zinc. $\mathrm{L}=$ Lente. $\mathrm{H}=$ Highly purified. $\mathrm{O}=$ Oral hypoglycaemic agents.

Skin biopsy samples were taken from the edge of lipoatrophic areas in eight patients (cases 1-8), from the middle of lipoatrophic areas in three (cases 9-11), and from normal skin distant to injection sites in three (cases 12-14). The five control biopsy samples were taken from non-lipoatrophic areas that had recently been repeatedly injected with insulin. Biopsy tissue was snap-frozen in liquid nitrogen. Immunofluorescence analysis was performed as described. ${ }^{5}$ Cryostat sections were incubated with fluorescein-conjugated antisera specific for IgG, IgA, IgM, C1q, C3, and fibrin-fibrinogen (Dako Immunoglobulins Ltd). Sections were examined in both blue and ultraviolet light with a Leitz Ortholux incident light microscopy system. Insulin was 